\title{
UPAYA PENINGKATAN PENDAPATAN KELUARGA MELALUI USAHA PEMBUATAN SABUN CUCI TANGAN CAIR DI KELURAHAN BULUSAN KECAMATAN TEMBALANG KOTA SEMARANG
}

\author{
Kuswardani. DC', Nurhidayati ${ }^{2}$ \\ Fakuktas Ekonomi Universitas Semarang \\ Tlogosari Kulon, Pedurungan, Semarang City, Central Java 50198 \\ Email korespondensi :dhani_dc@yahoo.co.id
}

\begin{abstract}
ABSTRAK
Mencegah meluasnya covid-19 menjadi tanggungjawab setiap penduduk yang ada di Indonesia. Masyarakat yang berdomisili di Kelurahan Bulusan Kecamatan Tembalang kota Semarang juga merasa bertanggung jawab dengan diri sendiri, keluarga dan masyarakat yang ada disekitar mereka untuk melakukan pencegahan penyebaran covid-19 tersebut. Salah satu upaya yang dilakukan dengan mematuhi protokol kesehatan ketika terpaksa harus melakukan kegiatan diluar rumah. Protokol kesehatan yang paling sering harus dilakukan diantaranya adalah rajin mencuci tangan dengan sabun. Mencuci tangan dengan sabun yang paling mudah dan irit adalah dengan sabun cuci cair. Ketersediaan sabun cair yang dibutuhkan untuk mencuci tangan relatif sangat tinggi mengingat kelurahan Bulusan merupakan kelurahan yang berdekatan dengan kampus Undip. Kedekatan dengan kampus Undip identik dengan bermunculannya warung makan yang dapat dipastikan memerlukan sabun cuci tangan sebelum konsumen memanfaatkan warung makan tersebut. Peluang inilah yang ingin dimasuki team pengabdian kepada masyarakat untuk memberikan pelatihan membuat sabun cuci tangan cair. Tujuan jangka pendek dikonsumsi sendiri, sedangkan dalam jangka panjang dapat ditawarkan kepada masyarakat yang potensial membutuhkan ketersediaan sabun cuci tangan cair.
\end{abstract}

Kata kunci : covid-19, sabun cuci tangan cair

\section{ABSTRACT}

Preventing the spread of covid-19 is the responsibility of every citizen in Indonesia. People who live in Bulusan Village, Tembalang District, Semarang City also feel responsible for themselves, their families and the community around them to prevent the spread of covid-19. One of the efforts is to comply with health protocols when forced to do activities outside the home. The health protocol that most often has to do is to diligently wash hands with soap. Washing your hands with soap is the easiest and most economical way with liquid detergent. The availability of liquid soap needed to wash hands is relatively high considering that Bulusan is a village close to the Undip campus. Its proximity to the Undip campus is synonymous with the emergence of food stalls which certainly require hand washing soap before consumers take advantage of these food stalls. This opportunity is what the community service team wants to enter to provide training in making liquid hand washing soap. The short-term goal is selfconsumption, while in the long term it can be offered to people who potentially need the availability of liquid hand soap.

Keywords: covid-19, liquid hand washing soap 


\section{PENDAHULUAN}

Sejak awal tahun 2020, dunia sedang mengawali wabah Corona Virus Disease (COVID-19), sampai pada akhirnya Kamis (12/3/2020), COVID-19 ditetapkan sebagai pandemic global. Wabah corona yang menyebar sangat cepat membuat masyarakat panik. Siapa pun berpeluang terjangkit virus tsb. oleh karena itu, mengantisipasi diri dengan berbagai upaya pencegahan penting dilakukan Wabah COVID-19 yang kini meluas di banyak negara termasuk Indonesia, harus terus diwaspadai.

Mencegah virus corona dapat dilakukan dengan berbagai cara. Cara yang bisa dilakukan di antaranya selalu menggunakan masker ke mana pun pergi, sering mencuci tangan, menjaga daya imunitas tubuh, pola hidup sehat, menjaga kebersihan, mengonsumsi makanan sehat, olahraga, social distancing, hingga stay at home. Mencegah COVID-19 dengan membiasakan diri mencuci tangan dengan sabun secara rutin merupakan salah satu cara yang cukup ampuh sebagai pertahanan terbaik. Mencuci tangan dengan sabun merupakan cara mencegah masuknya kuman, virus dan bakteri melalui mulut, hidung dan mata yang mudah dilakukan.

Menjaga kebersihan tangan baik di kantor, sekolah, atau dimanapun merupakan hal yang sangat penting jika ingin terhindar dari sakit. Menjaga kebersihan itu sangat penting, karena kuman ada dimana-mana yang menyebabkan penyakit berbahaya, misalnya handle pintu, keran air, uang dan benda benda lainnya yang sering tersentuh tangan. Memilih sabun pencuci tangan, orang lebih memilih sabun cair. Penyebab dipilihnya sabun cair karena lebih mudah menggunakannya dan terdapat dalam kemasan yang tertutup rapat. Kondisi tersebut berakibat tidak mudah terkontaminasi bakteri, namun, harga sabun cair jauh lebih mahal dibandingkan dengan sabun batangan, apalagi jika kebutuhannya dalam jumlah banyak.

Kelurahan Bulusan merupakan salah satu kelurahan dari 12 kelurahan lainnya di Kecamatan Tembalang Kota Semarang yang mempunyai permasalahan dengan adanya wabah corona tersebut, berdasarkan data per Agustus 2020 ditemukannya 2 penderita baru yang harus diisolasi karena terkena corona.

Salah satu cara menekan laju virus corona dengan menggunakan sabun untuk mencuci tangan. Masyarakat diharapkan dapat membuat sabun cuci tangan sendiri dan bisa menjual sabun cuci tangan tersebut untuk meningkatkan pendapatan rumah tangga. Hal ini didukung oleh wilayah disekitar Bulusan merupakan wilayah di sekitar UNDIP yang banyak terdapat warung makan yang membutuhkan sabun cuci tangan. Protokoler kesehatan yang mengharuskan konsumen harus mencuci tangan sebelum masuk ke warung makan / rumah makan konsumen harus mencuci tangan terlebih dahulu dengan menggunakan sabun yang sudah disediakan oleh pemilik warung / rumah makan.

Kondisi tersebut menjadi peluang memproduksi sabun cuci tangan cair untuk dijual yang diharapkan dapat menambah pendapatan tanpa harus meninggalkan pekerjaan saat ini. Modal yang tidak terlalu besar dan dapat dilakukan diluar jam kerja serta proses pembuatannya yang mudah merupakan kesempatan untuk menjual sabun cuci tangan dan piring cair dengan pasar potensial yang cukup besar. Berdasarkan analisis situasi tersebut perlu diberikan penyuluhan dan pelatihan menekan laju covid dan peningkatan pendapatan melalui ketrampilan pembuatan sabun cuci tangan cair di Kelurahan Bulusan Kecamatan Tembalang Kota Semarang.

Bertambahnya penderita covid menyebabkan masyarakat ikut bertanggung jawab menekan / mengurangi laju pemaparannya, dengan cara selalu mencuci tangan dengan sabun. Masyarakat diharapkan dapat membuat sabun cuci tangan cair sendiri, selain digunakan sendiri sabun yang diproduksi tersebut juga dapat dijual sehingga menambah 
penghasilannya. Salah satu masyarakat potensial yang bisa dikembangkan untuk memperoleh penghasilan tambahan berada di Kelurahan Bulusan Kecamatan Tembalang.

Permasalahan yang dapat diidentifikasi antara lain :

1. Laju pertambahan penderita covid yang tinggi

2. Banyaknya penduduk yang ingin mengisi kegiatan di rumah yang bermanfaat di era pendemi.

3. 3.Dibutuhkan formula sabun cuci tangan cair untuk mencegah mudahnya tersebarnya virus covid-19

\section{METODE PELAKSANAAN}

\section{Tahap Persiapan}

Pelaksanaan pengabdian diawali dengan orientasi lapangan oleh team pengabdian untuk melakukan komunikasi dengan mitra, mengidentifikasi potensi dan sumber daya lokal untuk kepentingan penyusunan program.

\section{Tahap Kegiatan}

Pengabdian kepada Masyarakat direncanakan dengan menghadirkan masyarakat di kelurahan Bulusan Kecamatan Tembalang khususnya masyarakat yang berkeinginan memperoleh tambahan pendapatan. Pengabdian dilakukan dengan melakukan penyuluhan dan pelatihan membuat Sabun Cuci Tangan cair. Langkah-langkah operasional untuk melaksanakan Penyuluhan dan Pelatihan pembuatan sabun cuci tangan cair adalah :

1. Mengidentifikasi permasalahan mitra.

2. Penyuluhan pentingnya selalu cuci tangan untuk mengurangi penyebaran virus covid-19.

3. Praktek membuat sabun cuci tangan cair

4. Masyarakat mengerti dan memahami

5. Masyarakat bisa membuat sabun cuci tangan cair

6. Menjual dan menghasilkan tambahan pendapatan.

\section{HASIL DAN PEMBAHASAN}

\section{Realisasi Pelaksanaan Kegiatan.}

Media kegiatan Pengabdian kepada Masyarakat menggunakan Aula keluarahan Bulusan agar terpenuhi kebutuhan ruangan terbuka dengan sirkulasi udara cukup untuk melaksanakan kegiatan. Kegiatan Pengabdian kepada Masyarakat dilaksanakan secara offline meskipun masih dalam masa pandemic covid-19. Pertimbangan yang dipergunakan tim Pengabdian kepada Masyarakat dengan offline untuk memudahkan penyampaian pelaksanaan membuat sabun cuci tangan cair dan tetap mematuhi protokol kesehatan, dengan membatasi jumlah peserta sebanyak 20 orang.

Kegiatan penyuluhan dan pelatihan pembuatan sabun cuci cair ditujukan kepada tim penggerak PKK kelurahan Bulusan Kecamatan Tembalang Kota Semarang yang diharapkan anggota tim tersebut mampu membuat sabun cuci tangan cair dan menularkannya pada keluarga di wilayah kelurahan Bulusan. Langkah awal sebelum melakukan penyuluhan dan pelatihan adalah melakukan observasi wilayah yang tepat 
sebagai sasaran Tim PkM Fakultas Ekonomi Univrsitas Semarang. Diskusi dengan ketua penggerak PKK kelurahan Bulusan Kecamatan Tembalang Kota Semarang merupakan upaya Tim PkM memperoleh informasi riil agar Tim PkM tepat guna dan tepat sasaran memberikan penyuluhan dan pelatihan. Langkah terakhir yang dilakukan Tim PkM adalah menentukan jadwal pelaksanaan kegiatan Pengabdian kepada masyarakat.

1. Tahapan kegiatan diawali dengan memberikan penjelasan bahan yang dibutuhkan untuk membuat sabun cuci tangan cair yaitu

a. Sabun batangan (merk dan warna sesuai selera) ukuran $100 \mathrm{ml}$

b. Air panas $700 \mathrm{cc}-1.000 \mathrm{cc}$

c. Solet sebagai pengaduk

d. Baskom untuk mengaduk parutan sabun dengan air panas

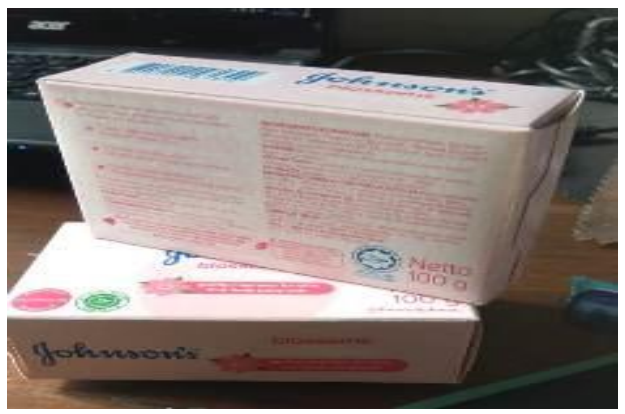

Gambar 1. Sabun Batangan

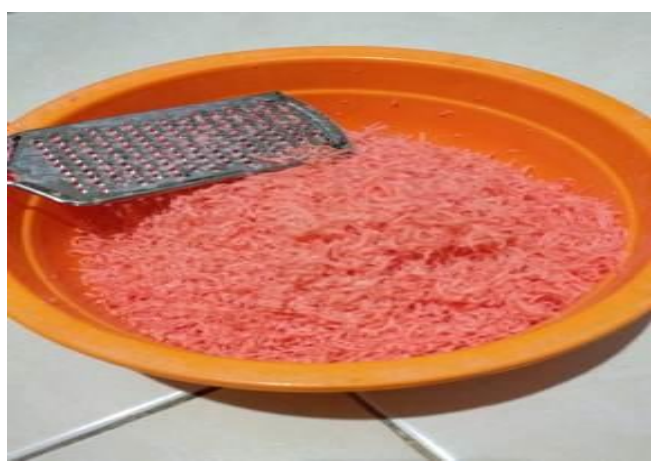

Gambar 3. Parutan Sabun

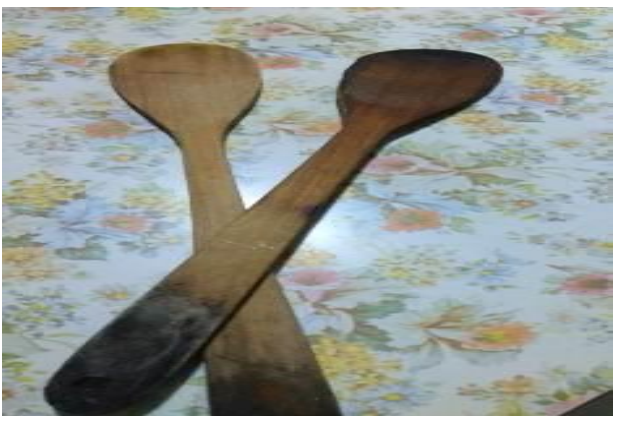

Gambar 4. Solet

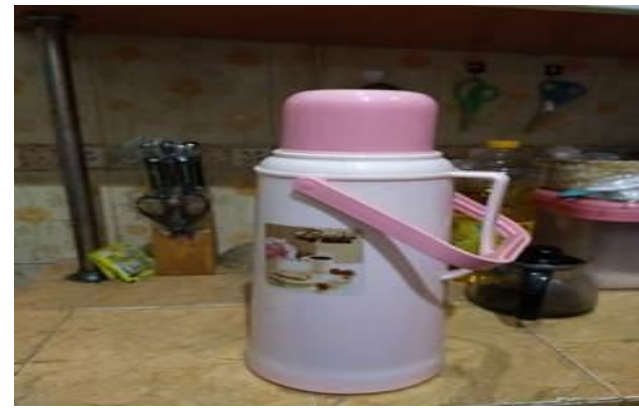

Gambar 2. Air Panas
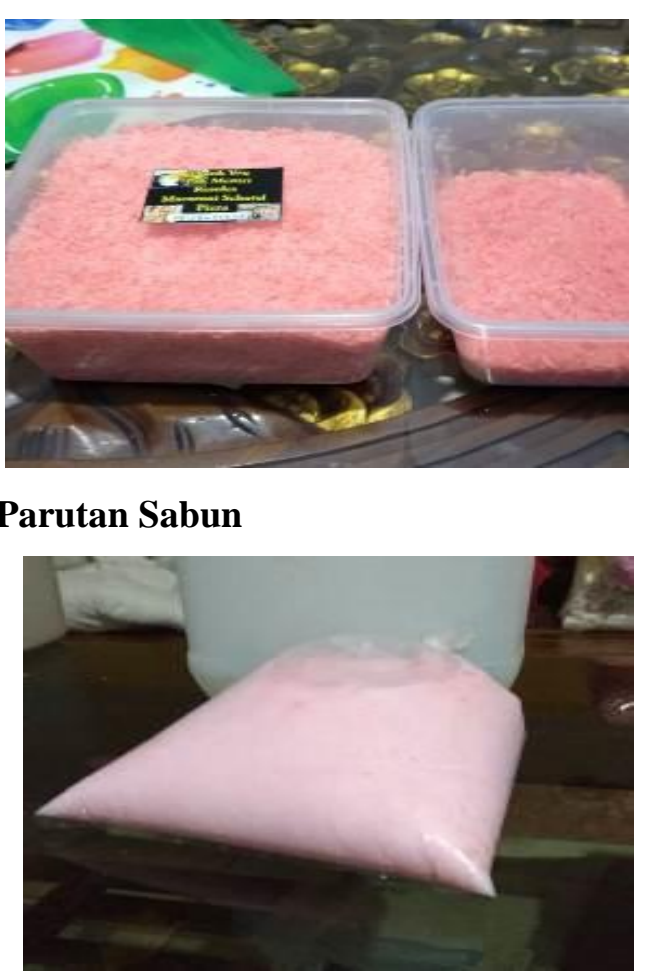

Gambar 5. Sabun cuci tangan cair 
2. Cara membuat sabun cuci tangan cair

a. sabun batangan diparut hingga halus

b. masukkan air panas sedikit demi sedikit sambil diaduk kedalam baskom

c. diaduk terus sampai air habis dan sabun seluruhnya bercampur dengan air

d. siap langsung bisa digunakan

\section{Catatan :}

untuk mempercepat proses mengaduk bisa juga dilakukan diatas api kompor dengan terus menerus diaduk
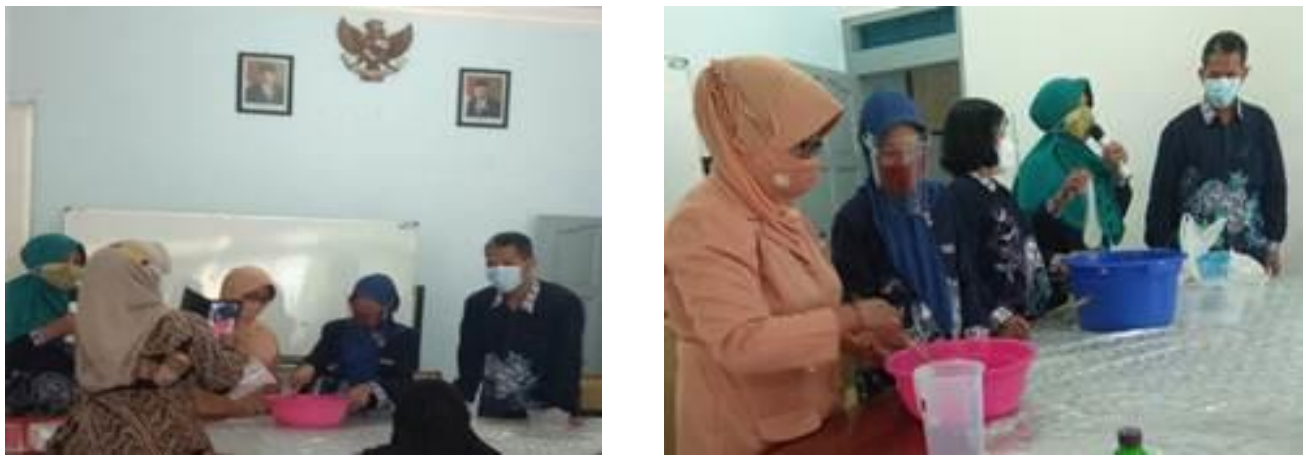

Gambar 6. Pelaksanaan Kegiatan

\section{Sasaran Pengabdian kepada Masyarakat}

Sasaran kegiatan Pengabdian kepada Masyarakat adalah Tim Penggerak PKK Kelurahan Bulusan Kecamatan Tembalang Kota Semarang, dengan bentuk kegiatan penyuluhan dan Pelatihan pembuatan sabun cuci tangan cair. Jumlah peserta kegiatan PkM 20 orang yang mewakili Kelurahan Bulusan Kecamatan Tembalang Kota Semarang.

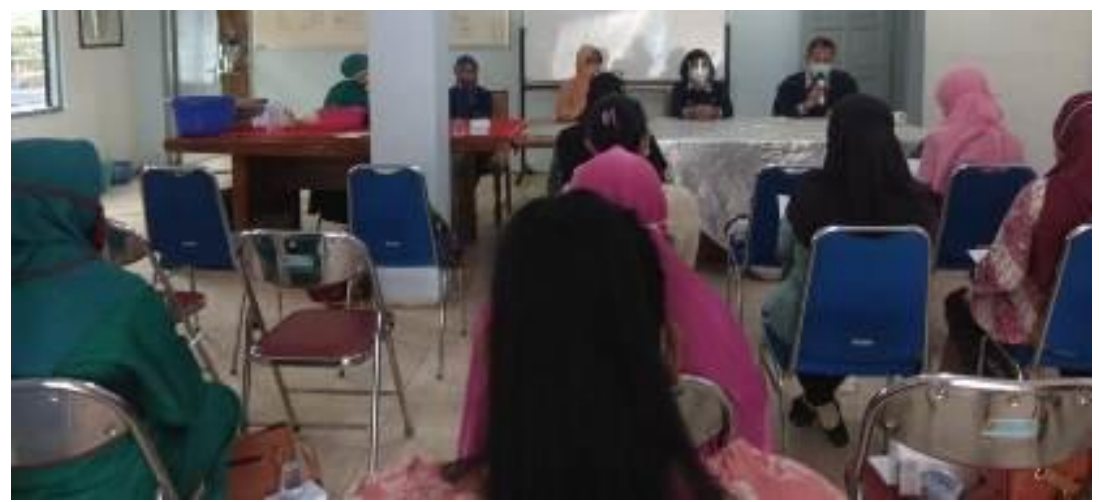

Gambar 7. Pelaksanaan Kegiatan

\section{Output dan Outcome.}

Output dari kegiatan Pengabdian kepada Masyarakat antara lain :

a. Peserta penyuluhan dan pelatihan memperoleh wawasan membuat sendiri sabun cuci tangan cair. 


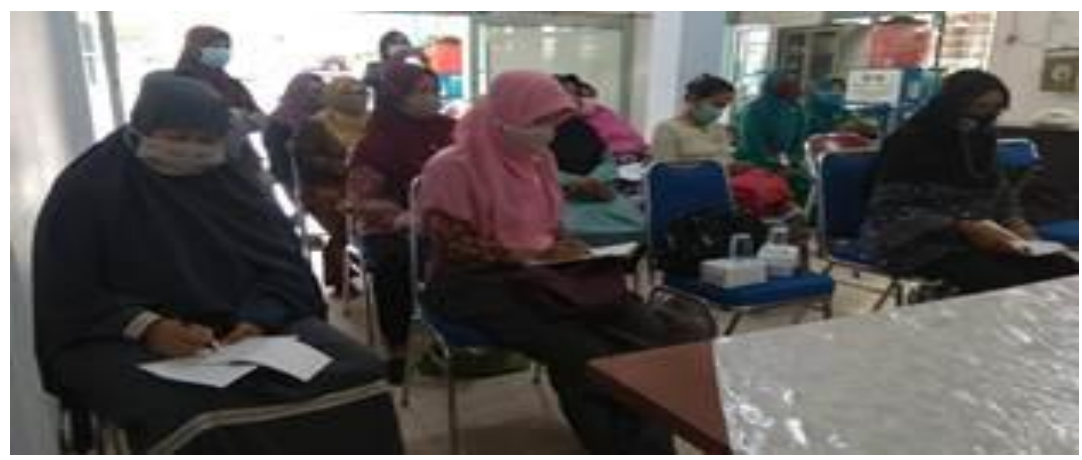

Gambar 8. Pelaksanaan Kegiatan

b. Penyuluhan dan Pelatihan dapat menghasilkan pemahaman dan kemampuan membuat sabun cuci tangan cair dan sekaligus mampu menularkan kepada keluarga di lingkungan kelurahan Bulusan.

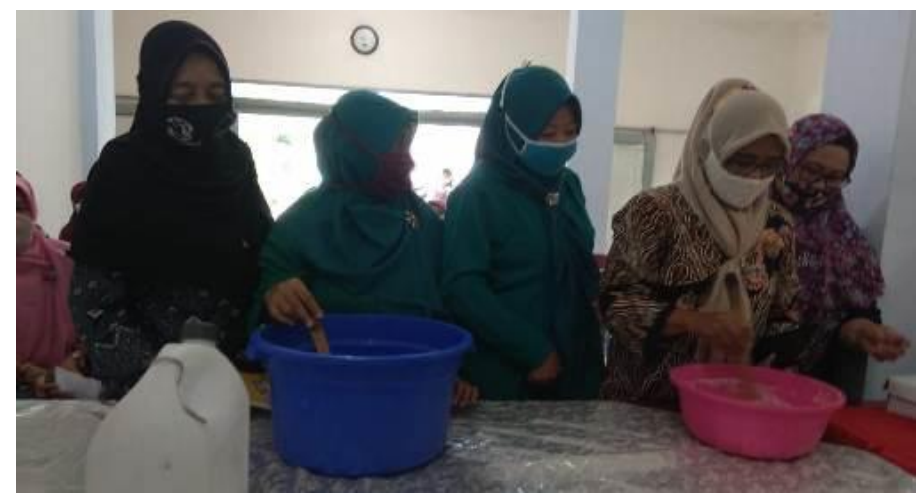

\section{Gambar 9. Pelaksanaan Kegiatan}

c. Evaluasi penyuluhan dan pelatihan menggunakan beberapa pertanyaan yang harus dijawab oleh peserta, dan sebagai apresiasi diberikan doorprize.
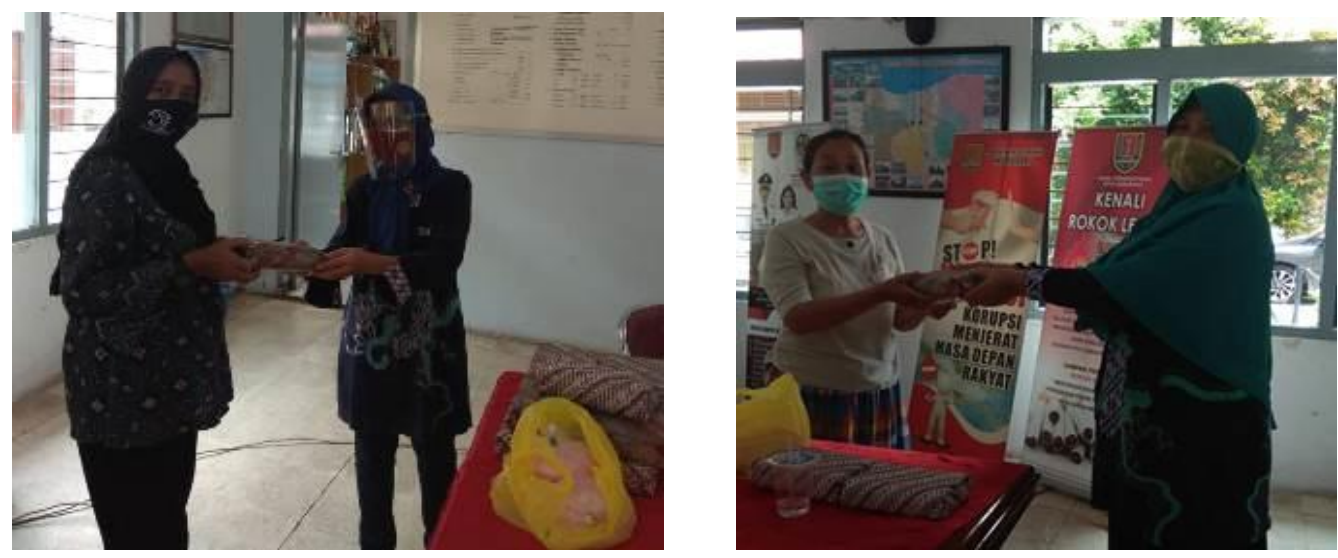

Gambar 10. Pelaksanaan Kegiatan 


\section{Outcome}

Outcome kegiatan Pengabdian kepada Masyarakat diantaranya :

a. Diharapkan dapat meningkatkan pengetahuan dan pendapatan keluarga sasaran

b. Diharapkan berdampak kesadaran masyarakat selalu hidup bersih melalui cuci tangan sehingga dapat mengurangi atau bahkan menghentikan penyebaran Covid19.

c. Universitas Semarang, khususnya Fakultas Ekonomi semakin dikenal masyarakat akan kepedulian mencegah merebaknya covid-19.

\section{KESIMPULAN}

Program penyuluhan dan pelatihan dapat diselenggarakan dengan baik dan berjalan lancar sesuai dengan rencana kegiatan yang telah disusun dan mematuhi protokol kesehatan. Kegiatan ini mendapat sambutan sangat baik, terbukti dengan keaktifan peserta mengikuti praktik membuat sabun cuci tangan cair sampai waktu pelatihan berakhir.

Peserta pelatihan berharap kegiatan penyuluhan dan pelatihan dilakukan secara berkala dan berkesinambungan. Mereka memberikan masukan bidang kegiatan yang dibutuhkan oleh kelompok masyarakat setempat sesuai dengan potensi di kelurahan tersebut, sehingga diharapkan dapat membantu peningkatan perekonomian rumah tangga

\section{DAFTAR PUSTAKA}

Joseph P. Cannon, William D Perreat, E. Jerome. (2018). Pemasaran Dasar Pendekatan Manajerial Global , Penerbit Salemba Empat , Jakarta..

Kotler \& Armstrong , 2016, Dasar-dasar Pemasaran, Penerbit PT Indeks, Jakarta

Soerata M. 2015, Memburu Rupiah Mengubah Peluang Menjadi Uang, LP3KI , Yogyakarta.. 